\title{
Mechanisms of tamoxifen resistance
}

\author{
Alistair Ring and Mitch Dowsett
}

Academic Department of Biochemistry, Royal Marsden Hospital, Fulham Rd, London. SW3 6JJ, UK

(Requests for offprints should be addressed to M Dowsett; Email: mitch@icr.ac.uk)

\begin{abstract}
The anti-oestrogen tamoxifen is the most commonly used treatment for patients with oestrogenreceptor (ER)-positive breast cancer. Although many patients benefit from tamoxifen in the adjuvant and metastatic settings, resistance is an important clinical problem. The target of tamoxifen in vivo is the ER. Over the last decade many advances have been made in our understanding of the biology of the ER which may help to explain how resistance to tamoxifen develops. Such mechanisms may include changes in the expression of $E R \alpha$ or $E R \beta$, alterations in co-regulatory proteins, and the influences of cellular kinase signal transduction pathways. The experimental and clinical evidence supporting these mechanisms of tamoxifen resistance are discussed in this review.
\end{abstract}

Endocrine-Related Cancer (2004) 11 643-658

\section{Introduction}

The anti-oestrogen tamoxifen is the most commonly used treatment for patients with oestrogen-receptor alpha (ER)-positive breast cancer. As an adjuvant therapy in early breast cancer tamoxifen improves overall survival, and its widespread use is thought to have made a significant contribution to the reduction in breast cancer mortality seen over the last decade (Early Breast Cancer Trialists' Collaborative Group 1998, Peto et al. 2000). In previously untreated metastatic breast cancer, more than $50 \%$ of patients with ER-positive tumours achieve an objective response or tumour stabilisation with tamoxifen (Lippman \& Allegra 1980, Paridaens et al. 1980, Campbell et al. 1981, Stewart et al. 1982, Ingle et al. 1991, Jaiyesimi et al. 1995). Tamoxifen may also have clinical utility as a preventative agent for hormone-dependent breast cancer (Cuzick et al. 2003). Despite the obvious benefits of tamoxifen in these treatment settings, almost all patients with metastatic disease and as many as $40 \%$ of patients receiving adjuvant tamoxifen eventually relapse and die from their disease. The biological mechanisms underlying intrinsic (de novo) and acquired resistance to tamoxifen are therefore of considerable clinical significance. Better understanding of these mechanisms may suggest novel strategies to overcome tamoxifen resistance and make further improvements in breast cancer survival.

\section{Oestrogen receptor mechanism of action}

The target of tamoxifen in vivo is the ER, and levels of ER expression are the best predictor of benefit from tamoxifen (Early Breast Cancer Trialists' Collaborative Group 1998). Therefore understanding the biology of the ER is critical to understanding how resistance to tamoxifen may develop.

The ER is a member of the nuclear receptor family of ligand-activated transcription factors. After entering the cell, oestrogen binds the ER, which dissociates from heat shock proteins and undergoes conformational changes, phosphorylation and dimerization before binding to the oestrogen response elements (ERE) upstream of oestrogen-dependent genes. This is referred to as the classical mode of action. ERs can also regulate gene expression without interacting with DNA directly, via other transcription factors such as the Fos/Jun activating protein1(AP-1) complex (non-classical mode) (Kushner et al. 2000, De Nardo et al. 2003, Schiff et al. 2003). Recent data also indicate that cytoplasmic membrane ER activity may interact directly with key growth-factor dependent kinases, although the biological significance of these nongenomic effects of ER is not fully understood. (Fig. 1).

The binding of ER to the ERE leads to alterations in transcription of oestrogen regulated genes. Recent data using microarray analysis to assess gene expression in the MCF7 cell line, suggests that the majority $(70 \%)$ of 

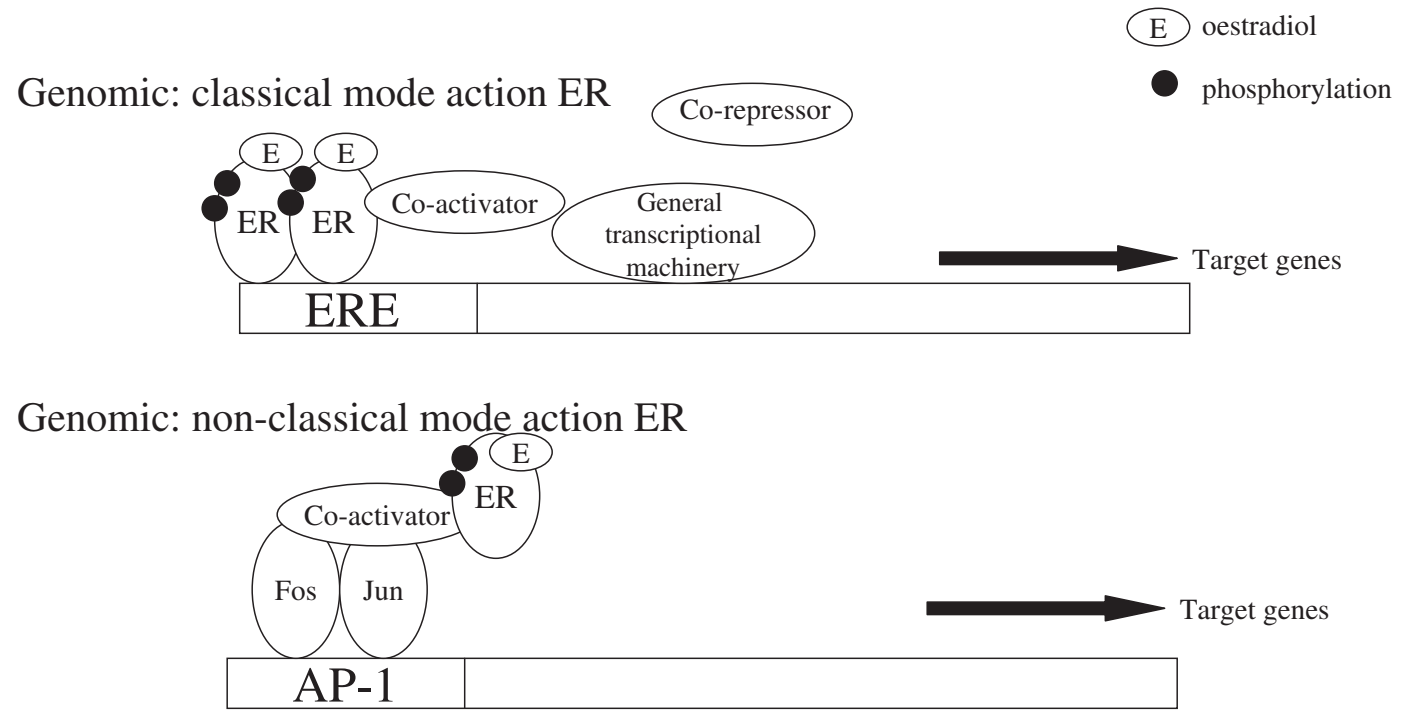

Non-genomic: mode action ER

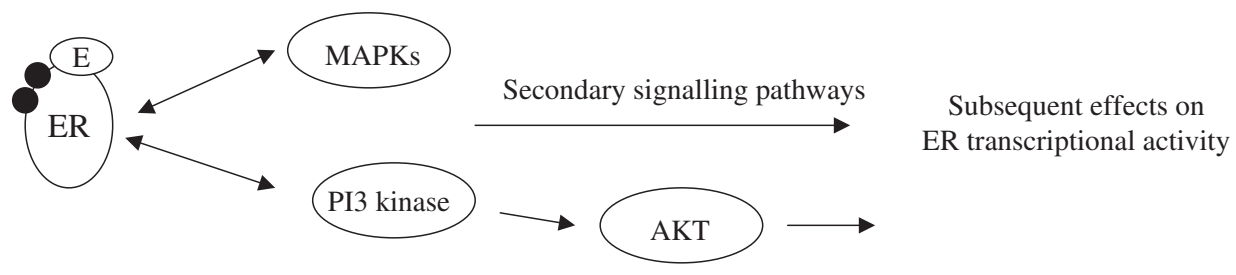

Figure 1 The genomic (classical and non-classical) and non-genomic actions of the ER

oestrogen-regulated genes are down-regulated by treatment with oestradiol (Frasor et al. 2003). Those genes down-regulated were shown to be transcriptional repressors, anti-proliferative and pro-apoptotic genes. Conversely there was up-regulation of positive proliferation regulators including genes involved in cell cycle progression (Frasor et al. 2003). Where up-regulation does occur, this is mediated by two distinct transactivation domains: Activating Function (AF)-1 (close to the $\mathrm{N}$ terminus) and AF-2 (in the ligand-binding domain). AF-1 activity is regulated by phosphorylation and is hormone-independent. AF-2 is integral to the ligand-binding domain (LBD) and therefore is hormone-dependent. AF-1 and AF-2 act synergistically in most cells, but certain gene promoters, sometimes as a result of their cellular context, can be independently transactivated by AF-1 or AF-2 alone (Gronemeyer 1991, Osborne et al. 2001). This promoter- or cell-dependence of ER-mediated transcription may be further modulated by the presence of coregulatory proteins which are recruited to and interact with promoter-bound receptor-ligand complexes. Coactivators which enhance transcription and co-repressors which suppress transcription have both been described.
Co-activators include the p160 family which stimulate ER activity via interaction with AF-2. The three members are the nuclear-receptor co-activator 1 (NCoA1 also known as SRC1), NCoA2 (TIF2 or GRIP1) and NCoA3 (AIB1, TRAM1, RAC3 or ACTR)(McKenna et al. 1999, Leo \& Chen 2000). Other coactivators include the SWI/ SNF complexes, CREB-binding protein (CBP), p300/ CBP-associated factor (PCAF), and the TRAP/DRIP/ SMCC complex (Chen et al. 1997, Sudarsanam \& Winston 2000, Ito \& Roeder 2001, Vo \& Goodman 2001). These proteins associate with each other and the general transcription machinery of the cell to form large complexes capable of synergistically activating oestrogendriven transcription. Many also have histone-acetyltransferase (HAT) activity which leads to chromatin decondensation and increased rates of transcriptional initiation. Two co-repressor proteins have also been described: nuclear receptor co-repressor 1 (NCoR1) and NCoR2 (also known as SMRT) (Chen \& Evans 1995, Horlein et al. 1995, Heinzel et al. 1997, Nagy et al. 1997). Co-repressors influence transcription at least in part by recruitment of histone-deacetylase complexes (HDAC) which lead to chromatin-condensation and decreased rates of transcriptional initiation. 


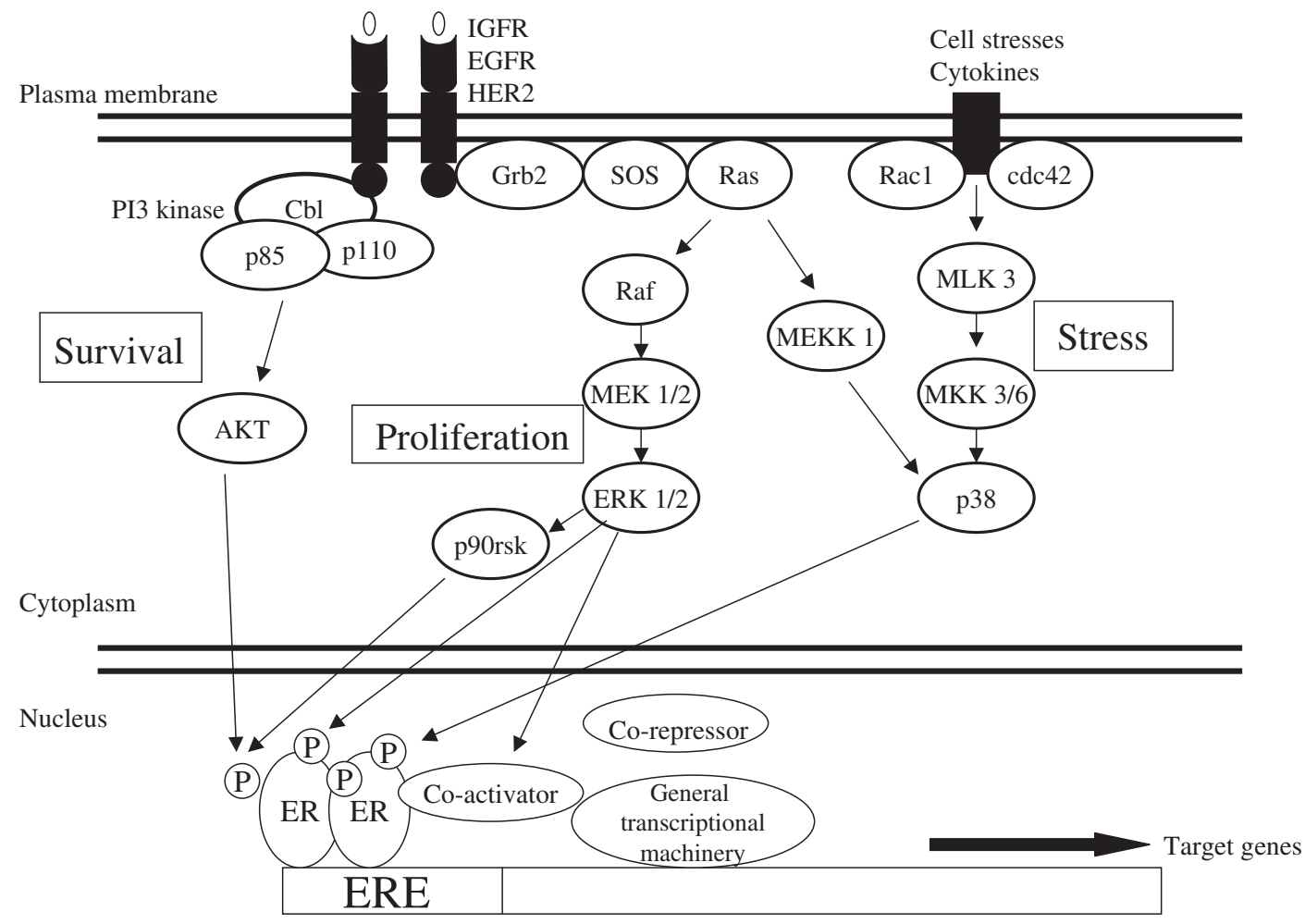

Figure 2 The cellular kinase pathways interacting with ER function (with thanks to Dr Lesley-Ann Martin)

The ligand bound ER complex in association with coregulatory proteins cannot be regarded in isolation from other pathways in the cell. Both the ER itself and co-regulatory proteins can be subject to phosphorylation at multiple sites by numerous cellular kinases, raising the possibility of further influences on ER-mediated transcription. When oestrogen binds to ER there are complex interactions which effect the ultimate influence of oestrogen-binding on transcription of oestrogen-responsive genes (Fig 2).

Over recent years, data has accumulated to suggest that in response to its ligand, membrane- or cytoplasmassociated ER can interact directly with key growth-factor dependent kinases (Kelly \& Levin 2001). This non-genomic action occurs rapidly following ligand-binding and is independent of gene transcription. The form in which the ER mediates these non-genomic effects and its cellular localisation requires further study. However using Western blotting, $E R \alpha$ has been shown to be present in the plasmalemmal caveolae (Kim et al. 1999), and in further studies a $46 \mathrm{kD}$ ER splice-variant has been identified, expressed in the plasma membrane ( $\mathrm{Li}$ et al. 2003). Oestrogen-activated membrane ER $\alpha$ has been shown to activate the insulin-like growth factor-1 receptor (IGF-1R) cell signalling cascade by direct binding to IGF-1R, followed by its phosphorylation, a process that was found to be dependent on mitogen-activated protein kinase (MAPK) kinase activity (Kahlert et al. 2000). In addition, ligand activated membrane ER can phosphorylate and activate epidermal growth factor receptor (EGFR), and can interact directly with a number of other key signalling molecules and pathways including members of the Src family, matrix metalloproteinases, G-proteins and the regulatory subunit of phosphatidyl-inositol-3 $\mathrm{OH}$ kinase (PI3K) (Sun et al. 2001, Migliaccio et al. 2002, Wong et al. 2002, Razandi et al. 2003). Although these effects are initially independent of gene transcription, activation of key secondary signalling pathways may mean subsequent effects on ER transcriptional activity are observed (Sun et al. 2001, Wong et al. 2002). Therefore the genomic and non-genomic actions of the ER are not necessarily independent and under some circumstances may represent inter-related complementary pathways.

When tamoxifen binds to the ER it leads to different conformational changes to those observed when oestrogen binds. Oestrogen binds within the hydrophobic pocket of the LBD and it is sealed inside by helix 12 . The ensuing conformational change activates AF-2. In contrast, studies examining the crystal structure of the $\mathrm{ER} \alpha \mathrm{LBD}$ when bound to 4-hydroxytamoxifen suggest 
that under these circumstances helix 12 is prevented from sealing the binding pocket (Shiau et al. 1998). This repositioning of helix 12 prevents the binding of coactivators and hence AF-2 transcription is prevented. Therefore tamoxifen inhibits AF-2 activation and functions as an antagonist on genes which rely on the AF-2 region for ER-mediated transcription. However, in genes where AF-2 function is redundant and transcription is driven by the AF-1 domain, tamoxifen may function as an agonist (Tzukerman et al. 1994, McDonnell et al. 1995). The predominance of AF-1 or AF-2-activated genes in particular tissues (for example uterus and breast respectively) has led to the apparent tissue selectivity of tamoxifen in its agonist and antagonist activity and the derivation of the acronym SERM (selective oestrogen receptor modulator) to describe its mode of action. The potential for the agonist activity of tamoxifen to outweigh its antagonist effects has been a key focus of research on tamoxifen resistance.

When tamoxifen is bound to the ER it also interacts with co-repressor molecules which result in suppression of its agonist activity (Lavinsky et al. 1998). Therefore, altered availability or recruitment of co-regulators to the tamoxifen-ER complex probably contributes to the tissue dependence of tamoxifen effects, and may also underlie some tamoxifen resistance. The complexity of ER activation and tamoxifen interaction with ER provides several potential mechanisms by which resistance to tamoxifen might evolve.

\section{Mechanisms of resistance Loss of ER $\alpha$ expression/function}

Since the effects of tamoxifen are primarily mediated through the ER, and the degree of ER expression is a strong predictor of responses to tamoxifen, loss of ER expression could confer resistance to therapy. Indeed, lack of ER expression is the dominant mechanism of de novo resistance to tamoxifen, with the majority of ER/PgR negative tumours not responding to anti-oestrogens (Lippman \& Allegra 1980, Paridaens et al. 1980, Campbell et al. 1981, Stewart et al. 1982, Ingle et al. 1991, Jaiyesimi et al. 1995). We have previously used an immunohistochemical assay to determine ER status in 72 paired biopsies taken before treatment and at progression or relapse on tamoxifen (Johnston et al. 1995). Patients whose tumours were treated with primary tamoxifen and responded prior to developing acquired resistance, frequently (but not always) remained ERpositive; 16 out of $18(89 \%)$ were ER-positive pretreatment, and 11 out of $18(61 \%)$ were positive on relapse. In a second similar series, tissue microarrays were constructed from biopsy samples taken pre-treatment and at relapse from patients treated with adjuvant tamoxifen. Of the 29 patients who were ER-positive pre-treatment, five $(17 \%)$ became ER-negative at relapse (Dowsett et al. 2003). Therefore, although ER expression may be lost in some patients who develop acquired tamoxifen resistance, and be the mechanism of resistance in these patients, the majority still express ER at progression. In fact up to $20 \%$ of patients who have relapsed on tamoxifen respond to aromatase inhibitors or to the ER-down-regulator fulvestrant suggesting that the ER continues to regulate growth even in many tamoxifen-resistant patients (Howell et al. 2002, Osborne et al. 2002).

Mutations of the ER genes may lead to a functionally negative ER phenotype without loss of ER expression as determined by protein-based immunohistochemical assays. Using site-directed mutagenesis in the AF-2 region of the mouse ER, it is possible to reduce oestrogendependent transcriptional activation, without significantly affecting hormone and DNA binding (Mahfoudi et al. 1995). A mutation substituting aspartate for tyrosine at position 351 has been identified in a tamoxifen-stimulated cell line (Wolf \& Jordan 1994). More recently substitution of aspartate with glycine at amino acid 351 in the ER has been shown in an experimental system to silence the agonist activity of 4-hydroxytamoxifen (MacGregor Schafer et al. 2000).

Although mutations in the ER which alter the effects of bound anti-oestrogens can be generated in vitro, and can be detected in some resistant cell lines, it is relatively uncommon to detect such mutations in patients (Karnik et al. 1994, Roodi et al. 1995). In a previous collaboration we screened 96 breast carcinomas for base mutations in the ER gene (Anderson et al. 1997). No somatic mutations were detected, although it should be noted that the primers used in the constant denaturant gel electrophoresis (CDGE) and the single-strand conformation polymorphism (SSCP) were located too close to the intron/exon boundaries to detect splice mutations. Zhang and colleagues screened 30 tumours from patients with metastatic breast cancer for mutations in the ER gene using SSCP (Zhang et al. 1997). Three mis-sense mutations were identified, one of which substituted tyrosine537 in the ligand-binding domain for asparagine. This substitution conferred constitutive oestradiol-independent transcriptional activity which was virtually unaffected by tamoxifen.

A single amino-acid substitution changing lysine 303 to arginine has been detected in 20 of 59 hyperplastic breast lesions (Fuqua et al. 2000). This mutation produced a hypersensitive receptor, with enhanced binding of co-activators in the presence of low oestrogen levels. Subsequently it has been found that this mutation alters the crosstalk between $\mathrm{ER} \alpha$ and various $\mathrm{ER} \alpha$ 
pathways that normally downregulate ER signalling (Cui et al. 2002). Such loss of regulation could theoretically enhance ER-mediated cell growth and contribute to the development of resistance.

In addition to genetic changes, epigenetic changes such as $\mathrm{CpG}$ island hypermethylation may cause transcriptional inactivation of the ER gene (Ottaviano et al. 1994). In a recent study the methylation status of 449 $\mathrm{CpG}$ dinucleotides in 177 candidate genes was analysed in 200 ER and/or progesterone receptor positive tumours from patients with recurrent breast cancer who had received tamoxifen (Martens et al. 2003). A predictive score was developed, based on promoter methylation status, and could be used to identify those likely to respond to tamoxifen. Further study of this approach in independent data sets should be undertaken in order to better confirm its validity.

So there is experimental data to suggest that ER mutations may contribute to tamoxifen resistance, and such mutations are detected, albeit infrequently, in clinical samples. However when they do occur their clinical contribution to tamoxifen resistance is not always apparent, and resistance certainly occurs in their absence.

\section{Altered expression of ER $\beta$}

In 1996, a second ER was cloned from a rat prostate cDNA library (Kuiper et al. 1996) and subsequently the human homologue was cloned (Mosselman et al. 1996). The gene was named ER $\beta$ to distinguish it from the classical ER which was renamed $\operatorname{ER} \alpha$. ER $\beta$ occurs in several variant forms and is expressed in both normal and malignant breast tissue (Fuqua et al. 1999, Leygue et al. 1999, Palmieri et al. 2002). In a paper published by Roger et al. (2001) decreased expression of $\operatorname{ER} \beta$ protein was observed in pre-invasive mammary tumours compared with normal or benign lesions, leading the authors to suggest a protective effect of ER $\beta$ against the mitogenic effects of oestrogen in mammary premalignant lesions (Roger et al. 2001).

$\mathrm{ER} \beta$ is highly homologous to $\mathrm{ER} \alpha$ in its DNA and LBDs, and binds oestradiol with similar affinity to ER $\alpha$. There is conflicting data concerning the relative coexpressions of $E R \alpha$ and $E R \beta$ and their associations with established prognostic variables, endocrine responsiveness and survival (Dotzlaw et al. 1999, Jarvinen et al. 2000, Mann et al. 2001, Omoto et al. 2001, Iwase et al. 2003, Fuqua et al. 2003). However, it appears that in experimental systems the two ERs signal in different ways depending on the ligand and response element (Paech et al. 1997). Paech and colleagues transfected HeLa cells with either an $\mathrm{ER} \alpha$ or $\mathrm{ER} \beta$ expression plasmid that contained a luciferase gene under the transcriptional control of an ERE. Both ER $\alpha$ and ER $\beta$ showed the same pattern of transactivation with the ligands $17 \beta$ oestradiol, raloxifene, diethylstilboestrol (DES), tamoxifen and ICI 164,384. However when ligand-induced transactivation behaviour of ER $\alpha$ and ER $\beta$ at an AP-1 site was examined, different patterns of transactivation were seen. With $\mathrm{ER} \alpha$, all five ligands stimulated luciferase transcription at an AP-1 site. In contrast, when ligand activation of ER $\beta$ at an AP-1 element was assessed, treatment with DES and $17 \beta$ oestradiol did not increase luciferase transcription, but raloxifene, tamoxifen and ICI 164,384 did (Paech et al. 1997). Therefore in oestrogen target tissues where signalling from ER-dependent AP-1 elements occurs, ER $\alpha$ and ER $\beta$ will have different effects on transcription in response to ligand-binding.

It is also interesting to note that using RT-PCR, median ER $\beta$ mRNA levels were approximately 2-fold higher than $\mathrm{ER} \alpha$ levels in tamoxifen-resistant tumours compared with tamoxifen-sensitive tumours (Speirs et al. 1999). However more work is required to establish whether altered expression of ER $\beta$ and its variants are important components of tamoxifen resistance.

\section{Endocrine adaptation}

In pre-menopausal women receiving tamoxifen, oestrogen levels rise significantly above normal levels (Ravdin et al. 1988). Elevated oestradiol levels could thereby limit ER saturation by tamoxifen and contribute to resistance. However elevated oestradiol levels have not been reported as being related to acquired tamoxifen resistance in premenopausal women and in post-menopausal women, changes in oestrone and oestradiol levels are not seen with tamoxifen treatment. Therefore this is not likely to be a dominant mechanism of resistance.

\section{Pharmacologic tolerance}

A common mechanism of drug resistance is the emergence of reduced intracellular concentrations of drug as a result of decreased influx or increased efflux; the latter is often mediated by the membrane pump P-glycoprotein. We have previously reported serum and intra-tumoural tamoxifen concentrations in 51 patients who had de novo resistance to primary tamoxifen, acquired resistance after an initial response or had relapsed during adjuvant tamoxifen (Johnston et al. 1993). There were no significant differences in serum tamoxifen concentrations between the groups with tamoxifen-resistant breast cancer. In contrast, significantly lower intra-tumoural tamoxifen levels were observed in the acquired resistance group than in the de novo resistance group. In the adjuvant relapse group of tumours, the median level was marginally higher than in the acquired resistance group and was not significantly different from the de novo group. 
Therefore this study suggests that acquired, but not de novo resistance to tamoxifen may be associated with reduced intra-tumoural concentrations in the presence of maintained serum levels. The mechanism responsible for altered tamoxifen accumulation is not understood, although P-glycoprotein is probably not responsible (Clarke et al. 1992). Sensitivity to tamoxifen could also be affected by a reduction in the intracellular availability of tamoxifen due to the presence of intracellular antioestrogen binding sites (Pavlik et al. 1992). The extent to which such a mechanism contributes to clinical resistance is not known. The fact that tamoxifen and its metabolites saturate the ER by more than $99.9 \%$ in post-menopausal women (Dowsett \& Haynes 2003) suggests that only exceptionally large changes in the disposition of tamoxifen could lead to resistance.

Increased metabolism of tamoxifen to agonistic metabolites is a further potential resistance mechanism (Osborne et al. 1991). Tamoxifen is metabolised in man to $\mathrm{N}$-desmethyltamoxifen and 4-hydroxytamoxifen. $\mathrm{N}$-desmethyltamoxifen is the major metabolite detected in the serum; although 4-hydroxytamoxifen has a greater affinity for the ER than tamoxifen, the levels in serum are very low. In one model of resistance, oestrogenic metabolites would compete with anti-oestrogenic metabolites for ER activation. However it has been proposed that very large increases in oestrogenic metabolites would be required to overcome intratumoural anti-oestrogen levels (Clarke et al. 2001), and serum levels of the major metabolites of tamoxifen have been shown to remain constant over several years of therapy (Fahey et al. 1989).

However in a recent study a further active metabolite was identified (4-hydroxy- $N$-desmethyltamoxifen) which was present in the blood at higher concentrations than 4hydroxytamoxifen (Stearns et al. 2003). The generation of this metabolite was found to be dependent on CYP2D6, and patients carrying the wild-type CYP2D6 allele who were treated with paroxetine had a decreased plasma concentration of 4-hydroxy-N-desmethyltamoxifen. (Paroxetine is a selective serotonin re-uptake inhibitor which is sometimes co-administered with tamoxifen in order to ameliorate hot flushes). In addition, women with a variant CYP2D6 allele receiving tamoxifen also had lower plasma concentrations of the metabolite (Stearns et al. 2003). These results indicate that both pharmacogenomic effects and pharmacological interactions may alter the metabolism and potentially the efficacy of tamoxifen.

\section{Alterations in co-regulatory proteins}

Co-activator and co-repressor proteins have important roles in mediating transcriptional activation by the ER, and therefore altered patterns of co-regulator expression may contribute to the tamoxifen resistance phenotype.

\section{Co-activators}

AIB1 (also known as SRC3, TRAM1, NCoA3, RAC3, ACTR and $p / C I P)$ is an ER co-activator which is overexpressed in over $50 \%$ of breast tumours (Anzick et al. 1997). It is also highly expressed in the MCF7 breast cancer cell line, and is essential for the growth of these cells in vitro and also when assessed in a mouse xenograft model (List et al. 2001). Under these circumstances AIB1 appears to have a rate-limiting role in hormone-dependent human breast tumour growth, and in cultured cells AIB1 enhances the agonist activity of tamoxifen (Webb et al. 1998). In a recent report AIB1 expression was assessed by Western blot analysis in 187 patients who had received adjuvant tamoxifen, and 119 patients who received no adjuvant therapy (Osborne et al. 2003). In the untreated patients, high AIB1 levels were associated with a better outcome when patients in the top quartile for AIB1 expression were compared with those in the lower three quartiles. In contrast, in the tamoxifen-treated patients, high AIB1 expression was associated with a worse diseasefree survival when regarded as a continuous variable (hazard ratio $1.43,95 \% \mathrm{CI}=1.03$ to $1.97 ; P=0.031$ ). Furthermore there may be important interactions between AIB1 and HER2 which may explain this outcome (see below). These data support the laboratory studies suggesting that high levels of ER co-activators may enhance the oestrogen agonist activity of tamoxifen and contribute to tamoxifen resistance. In contrast, data from our own laboratory did not show increases in mRNA expression of the co-activators RIP140, TIF-1 or SUG-1 in 19 tamoxifen-resistant breast tumour samples when compared with six tamoxifen treated or 21 untreated tumours (Chan et al. 1999). Experimental data suggest that overexpression of other co-activators such as SRC-1 may be able to enhance oestrogen-stimulated expression of target genes, and enhance the agonist activity of 4hydroxytamoxifen (Tzukerman et al. 1994, Smith et al. 1997). However to date there is no evidence of overexpression of SRC-1 in clinical samples taken from patients with tamoxifen-resistant breast tumours.

\section{Co-repressors}

When co-repressors are recruited to the ER, they form multi-subunit repressor complexes which include HDACs, facilitating chromatin condensation and inhibition of gene transcription (Lavinsky et al. 1998, McKenna et al. 1999). The co-repressors are usually only recruited when an antagonist, such as tamoxifen, is bound to the ER, and under these circumstances result in a repression of its agonist activity. A study published by Lavinsky and coworkers confirmed that NCoR only weakly asssociated with $\mathrm{ER} \alpha$ in the absence of ligand, but did so avidly in the presence of the mixed anti-oestrogen trans-hydroxyta- 
moxifen (Lavinsky et al. 1998). When NCoR activity was blocked using purified Ig $\mathrm{G}$ against NCoR, transhydroxytamoxifen was converted into an agonist in MCF7 cells. In further studies MCF7 cells were implanted into nude mice which were then treated with tamoxifen. NCoR levels (assayed on whole-cell extracts of the tumours) declined in many of the tumours that acquired resistance to the anti-proliferative effects of tamoxifen, relative to tumours retaining a response to the drug. Taken together, these data raise the possibility that progressive reductions in co-repressor activity during tamoxifen therapy may enhance the agonist effects of tamoxifen on the ER contributing to resistance. In a further clinical study there were no differences in the levels of the co-repressor SMRT mRNA in cohort of 19 tamoxifen-resistant breast tumour samples, compared with 21 untreated tumours but this study did not assess NCoR levels (Chan et al. 1999).

\section{Cellular kinase/signal transduction pathways}

Oestrogen receptor biology cannot be regarded in isolation from other intracellular signalling pathways. Over the last few years, a considerable body of evidence has emerged to suggest that there are multiple regulatory interactions between the ER, growth factor and other kinase signalling pathways. Hence growth factor receptor pathways may up-regulate and stimulate growth independently of the ER, or could communicate via cross-talk with the ER and thereby affect cell growth and patterns of resistance.

\section{Peptide growth factor signalling pathway}

Numerous studies suggest that cross-talk occurs between ER and growth factor receptor pathways, such as the EGFR/HER2 family and insulin-like growth factor receptor (IGFR) family. The ER can be phosphorylated at the serine-118 position within AF-1 by the MAPKs ERK1 and ERK2, which are downstream components of the HER2 signalling pathway (Fig. 2) (Kato et al. 1995). This enhances the sensitivity of the ER to ligand and potentially leads to ligand-independent activation (Bunone et al. 1996). Serine-167 in AF-1 is also phosphorylated by a component of the kinase-mediated growth factor signalling pathway, in this case ribosomal S6 kinase (RSK) which is itself activated by ERK1 and ERK2 (Joel et al. 1998). Therefore increased ERK activity could potentially contribute to resistance to endocrine therapy. Indeed, ERK1/2 expression and activity are increased in several breast cancer cell-line models of endocrine resistance (Coutts \& Murphy 1998, Shim et al. 2000), and increased ERK $1 / 2$ activity (assessed by phosphorylated MAPK immunostaining) correlates with shorter duration of response to endocrine therapy in clinical breast cancer (Gee et al. 2001).

In addition to activating ER directly, kinase-mediated growth factor signalling may also modulate ER activity indirectly by enhancing the activity of co-activators and attenuating co-repressor activity (Lavinsky et al. 1998, Font de Mora \& Brown 2000). These effects are most likely to be achieved by the phosphorylation of coregulators, which may in turn effect their nuclear sublocalisation (Hong \& Privalsky 2000, Wu et al. 2002). Therefore, it is possible that up-regulation of tyrosine-kinase growth factor receptor pathways during tamoxifen treatment may lead to loss of oestrogendependence and tamoxifen resistance.

The effects of the growth factor signalling pathways on the ER are bi-directional. When bound to ligand, ER can activate growth factor receptors and their downstream kinases, and signalling molecules apparently by direct interaction at the cell membrane (Kelly \& Levin 2001). A direct physical association between ER $\alpha$ and IGFR leads to activation of IGFR and the downstream ERK1/2 MAPK pathways (Kahlert et al. 2000). This interaction is blocked by the addition of the pure antioestrogen ICI 182,780 (fulvestrant) and by the MAPK inhibitor PD 98059. Therefore, ligand bound ER is capable of rapid activation of IGFR and its downstream signalling cascade. $\mathrm{ER} \alpha$ also appears to interact directly with HER2, and membrane-bound ER transactivates EGFR by phosphorylation (Chung et al. 2002, Razandi et al. 2003). Recent data also suggest that progesterone can interact with the IGFR pathway by induction of insulin receptor substrate-2 (IRS-2) mRNA levels (Cui et al. 2003). Short-term progestin treatment was also found to increase binding of IRS-2 to Grb-2 and the PI3K regulatory sub-unit p85, and lead to enhanced ERK and AKT activation, demonstrating that cross-talk between endocrine and growth factor receptor pathways occurs at several levels.

There is a considerable body of experimental evidence to implicate these pathways and their cross-talk in de novo resistance to tamoxifen. Transfection of HER2 cDNA into the oestrogen sensitive MCF7 cell line can generate transfectants (MCF/HER2-18) which express the HER2 receptor at a level 45-fold higher than the parental cell line (MCF7) or control transfected cells (MCF/neo-3) (Benz et al. 1993). When the three cell lines are implanted into ovariectomised nude mice, no tumours were produced in the absence of oestrogen. In oestrogen-supplemented mice, the MCF/HER2-18 xenograft grew most rapidly. When oestrogen was stopped and tamoxifen started, MCF7 and $\mathrm{MCF} /$ neo-3 tumour growth ceased immediately, whilst MCF/HER2-18 tumours continued to grow (Benz et al. 1993). These data suggest that HER2-transfected MCF7 
cells are oestrogen-dependent but tamoxifen-resistant. Similar experiments carried out by Pietras et al. (1995) confirmed that HER2 transfectants were tamoxifenresistant, but in vitro growth was found to be oestrogenindependent (Pietras et al. 1995). These latter studies also demonstrate that overexpression of HER 2 or its activation with heregulin leads to the down-regulation of ER, increase in ligand-independent ER phosphorylation and transcriptional activation. Furthermore when the MAP-kinase inhibitor U0126 was added to MCF7 cells transfected with HER2 it was found to restore the inhibitory effect of tamoxifen on cell proliferation (Kurokawa \& Arteaga 2001). These experiments provide evidence that overexpression of HER2 may be a primary mechanism of de novo resistance to tamoxifen.

There is also evidence from cell lines that overexpression of HER2/EGFR growth factor receptor pathways may contribute to acquired resistance to endocrine therapies. Continuous culture of MCF7 cells with either tamoxifen or the pure anti-oestrogen Fulvestrant has been shown to generate sublines which can tolerate the presence of these agents, and grow at rates equivalent to their parental lines (McClelland et al. 2001, Knowlden et al. 2003). Under these circumstances of anti-oestrogen resistance, parallel increases in EGFR and HER2 protein have been observed. In addition sensitisation to the effects of the EGFR tyrosine kinase inhibitor, gefitinib, have also been reported (Nicholson et al. 2001). It is therefore possible that acquired resistance to anti-oestrogens is facilitated by increases of EGFR/HER2 expression enabling stimulation of proliferation via this hormoneindependent pathway.

There is therefore pre-clinical evidence to support the presence of parallel inter-communicating growth stimulatory pathways in breast cancer cells. The relative activity of these pathways in an individual cell may be an important determinant of the efficacy of a treatment targeting a single pathway. The existence of cross-talk between the pathways adds a further level of complexity. Such a model would predict that increases in growth factor receptor pathway signalling would potentiate the ER pathway, which in turn would reactivate growth factor signalling pathway leading to further transcriptional activation of oestrogen-responsive genes and enhanced cross-talk. It is therefore possible to envisage that enhanced growth factor signalling pathway activity may circumvent tamoxifen inhibition of growth and contribute to endocrine resistance. The possibility of such a mechanism of resistance has important clinical implications as it infers that HER2-targeted therapy with trastuzumab and the EGFR tyrosine-kinase inhibitor gefitinib may be useful agents either to prevent or to circumvent tamoxifen resistance. However is there clinical evidence that overexpression of such pathways may contribute to resistance?

In the adjuvant setting several studies suggest that patients overexpressing HER2 may derive relatively less benefit from adjuvant tamoxifen (Carlomagno et al. 1996, Dowsett 1999, Knoop et al. 2001, De Placido et al. 2003). However this is not a universal finding and studies in both the adjuvant and metastatic settings have methodological limitations because they are retrospective, have small numbers of patients and use inconsistent methods to assess HER2 status (Berry et al. 2000, Stal et al. 2000), reviewed in (Ring \& Dowsett 2003). However studies undertaken in the neoadjuvant setting, have the substantial advantage that outcome data are based on objective responses to treatment, and ER and HER2 can be assessed directly in the lesion being measured. In our own studies, the effect on proliferation (measured by Ki67 levels) of hormone therapy was assessed at 2 and/or 12 weeks in biopsies from 115 patients with primary ERpositive breast cancer (Dowsett et al. 2001). (The patients in this analysis had participated in one of 3 neoadjuvant trials and had received tamoxifen, idoxifene, anastrozole or vorozole.) It was found that patients with tumours which overexpressed or amplified HER2, had an impeded anti-proliferative response to endocrine therapy, and that this was likely to be translated into clinical response, but the value of this observation was reduced by the mixture of endocrine agents included in the analysis.

In a study conducted by Ellis et al. (2001) 337 postmenopausal women who were ER-and/or PgR-positive on pre-treatment biopsy were randomly assigned to either primary letrozole or tamoxifen (Ellis et al. 2001). In 237 women a biopsy was also available for central testing of HER2/ EGFR. In the ER-positive tamoxifen-treated patients the response rate was $21 \%$ for those who expressed EGFR and/or HER 2 and $42 \%$ in those who were EGFRand HER2- negative, although this difference did not reach statistical significance $(P=0.095)$. For all ER-positive and /or PgR-positive patients the response rate was higher for letrozole compared with tamoxifen $(60 \%$ vs $41 \%$, $\mathrm{P}=0.004)$. However a novel finding was that in $\mathrm{ER}$ positive patients who were also EGFR- and/or HER2positive, the response rate was significantly higher to letrozole than to tamoxifen $(88 \%$ vs $21 \%, P=0.0004)$ (Fig. 3). In contrast there was no significant difference between response rates to letrozole and tamoxifen in the ER-positive, EGFR and HER2 negative patients (54\% vs $42 \%, P=0.078>$ ). In the IMPACT study 330 postmenopausal women with operable breast cancers were randomised to receive 3 months of neoadjuvant anastozole, tamoxifen or the combination (Smith et al. 2004). Thirtyfour of $239(14 \%)$ per protocol treated ER-positive patients were HER2-positive. In these patients the response rate to 

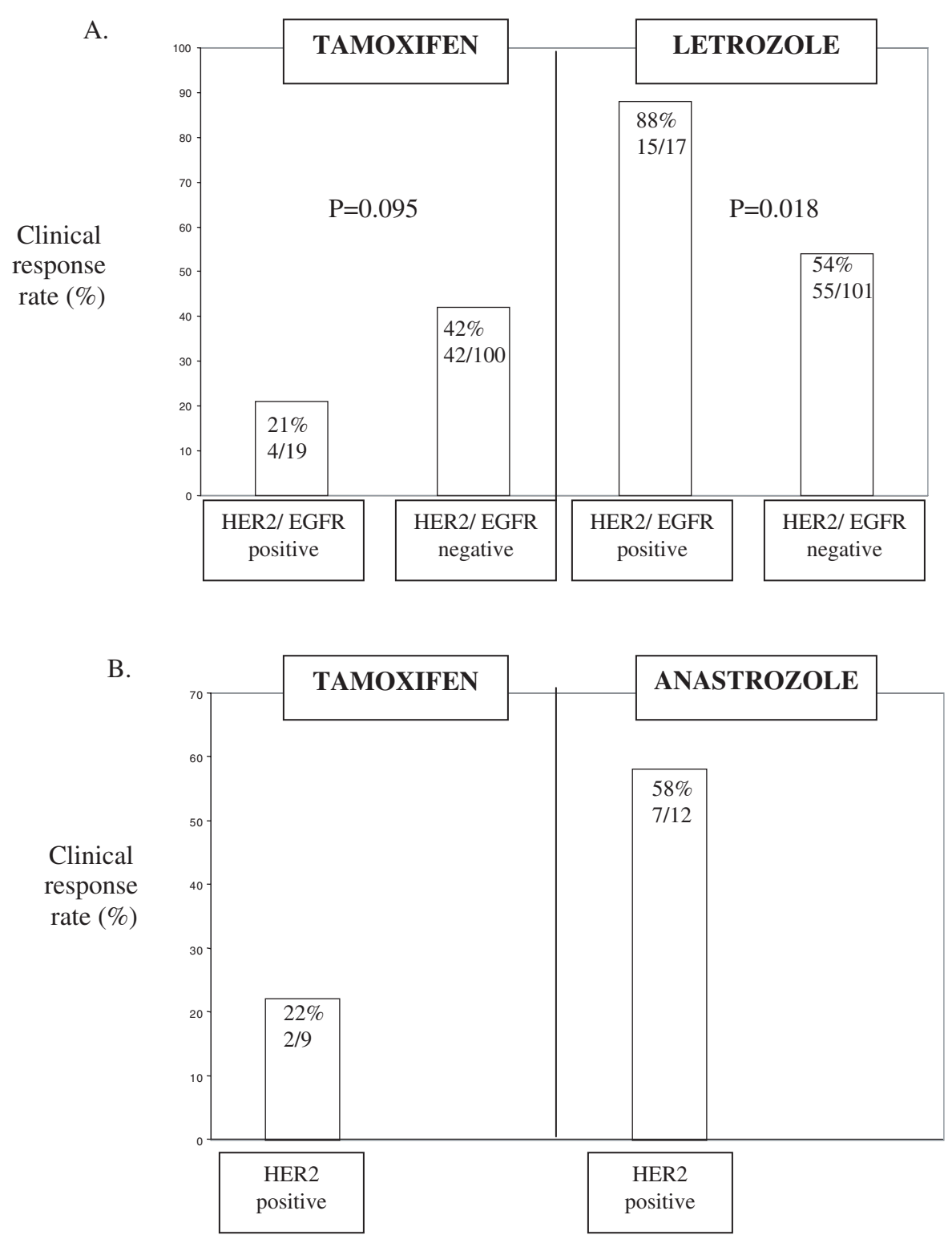

Figure 3 Clinical responses according to EGFR/HER2 status in patients treated with neoadjuvant endocrine therapy.

anastrozole $(58 \%)$ was higher than that to tamoxifen $(22 \%)$ although this did not reach statistical significance $(P=0.09)$. The suggestion from these studies is that women with HER2 positive tumours are differentially more likely to respond to aromatase inhibitors than to tamoxifen, a conclusion that is potentially highly important but bearing in mind the small sample sizes must be regarded as preliminary and will require confirmation.

Studies such as that reported by Ellis et al. (2001) concentrate on whether de novo overexpression of HER2 contributes to tamoxifen resistance. However many tumours are not resistant from the outset but rather exhibit an initial response or period of stabilisation before acquiring resistance to treatment. It is therefore a possibility that HER2 may contribute to acquired resistance by becoming overexpressed during the period of endocrine treatment, and thereby providing an alternative pathway for autonomous tumor growth. At our institution HER2 status was assessed in 155 patients who were progressing on tamoxifen treatment (Newby et al. 1997). 
Marginally higher levels of HER2 positivity were present in samples taken from patients who were progressing on tamoxifen compared with untreated tumors. However in the 61 patients in whom paired pre-treatment and relapse specimens were available, there was no significant increase in HER2 positivity. In contrast, in a second study tissue microarrays were constructed from biopsy samples taken pre-treatment and at relapse from patients who had received adjuvant tamoxifen (Dowsett et al. 2003). Paired data were available from 39 patients, of whom 29 were ERpositive. Of these 29 ER-positive patients, three were HER2-positive pre-treatment and remained so at relapse. However a further three patients who were HER2-negative pre-treatment became HER2 positive at relapse. This second (but smaller) study therefore supports the hypothesis of acquisition of tamoxifen resistance by HER2 overexpression in a proportion of patients.

The studies reviewed show that the contribution of HER2 overexpression to tamoxifen resistance is by no means certain. However as has already been discussed high levels of the co-activator AIB1 can reduce the antagonist effects of tamoxifen, and kinase-mediated growth factor signalling may enhance the activity of co-activators such as AIB1 (Font de Mora \& Brown 2000). Therefore, it is possible that in tumours with high levels of AIB1 which overexpress HER2, AIB1 may be further activated by signalling downstream of HER2 and the anti-tumour effectiveness of tamoxifen be reduced because of enhanced oestrogen-agonist activity. In this way, the assessment of AIB1 levels might complement and enhance the predictive value of HER2 (Schiff et al. 2003). There is clinical evidence to support this hypothesis (Osborne et al. 2003). One hundred and eighty seven patients treated with tamoxifen and 119 with no adjuvant systemic therapy were studied. It was found that only those tumours expressing both high AIB1 and high HER2 had a worse outcome with tamoxifen, whereas those patients with tumours with high HER2 or AIB1 had a good disease-free survival (Osborne et al. 2003). These data support the hypothesis that increased signalling through EGFR/HER2 may activate MAPK in turn activating ER and AIB1. In the presence of a phosphorylated ER and high levels of activated AIB1, the agonist activity of tamoxifen may be enhanced and resistance develop.

\section{PI3K cell survival pathway}

ER activity may also be influenced by the phosphatidylinositol-3-OH kinase (PI3K) pathway. When activated by tyrosine kinase receptors in response to growth factor stimulation, PI3K catalyses the formation of PIP3. One of the downstream targets of this pathway is the serine/ threonine protein kinase AKT, whose activation promotes cellular proliferation and anti-apoptotic responses
(Datta et al. 1999, Clark et al. 2002). There is evidence that ER $\alpha$ can bind in a ligand-dependent manner with the p85a regulatory subunit of $\mathrm{PI} 3 \mathrm{~K}$, leading to the activation of AKT and subsequent downstream effects (Simoncini et al. 2000). AKT is also a target of several other receptorstimulated pathways including IGF-1R, EGFR and HER2 (Clark et al. 2002). However the relationship with ER is reciprocal, in that PI3K activates AKT which phosphorylates the ER at serine-167 resulting in ligandindependent activation (Campbell et al. 2001).

The potential clinical importance of the relationship between the PI3K cell survival pathway and ER-mediated signalling has been demonstrated in two laboratory studies (Campbell et al. 2001, Clark et al. 2002). Clark and colleagues measured tamoxifen-induced apoptosis in different cell lines with and without the PI3K pathway inhibitor LY294002 (Clark et al. 2002). The addition of LY294002 to tamoxifen was found to significantly increase the pro-apoptotic effects of tamoxifen, particularly in the cell line with the highest endogenous levels of AKT activity. Campbell and colleagues transfected MCF7 cells with AKT reducing the inhibition of cell growth by tamoxifen, suggesting that high expression of AKT could be associated with tamoxifen resistance but there are no clinical data to address this (Campbell et al. 2001).

\section{Stress-activated protein kinase/c-junNH2 terminal kinase pathway.}

The ER protein may interact with the stress-activated protein kinase/c-junNH2 terminal kinase pathway either by binding with the Activating Protein-1 (AP-1) transcription complex or possibly by direct activation of ER by $\mathrm{p} 38$ MAPK.

AP-1 is a complex of proteins composed of Jun and Fos family members which dimerize and bind to DNA at AP-1 response elements (Angel \& Karin 1991). AP-1 transcriptional activity is increased by increased abundance of any of the components or by their phosphorylation by the Jun NH2-terminal kinases (JNKs) or stress activated protein kinases (SAPKs). These enzymes are activated by cellular stresses including oxidative stress (Kyriakis et al. 1994). It has been reported that the development of tamoxifen resistance in MCF7 cells is accompanied by increased AP-1 DNA binding (Dumont et al. 1996). These findings have been replicated in a panel of 30 primary human breast tumours with acquired tamoxifen resistance, compared with 27 untreated controls (Johnston et al. 1999). Similarly, but using a mouse xenograft model, Schiff and colleagues showed that tamoxifen-resistant tumours, compared with oestrogentreated tumours, had increased AP-1 dependent transcription and phosphorylated c-Jun and JNK levels (Schiff et al. 2000). In addition, they found that the conversion to a 
resistant phenotype was associated with an increase in oxidative stress (as measured by increases in superoxide dismutases and glutathione-S-transferase). It has been known for some years that tamoxifen can induce intracellular oxidative stress, and these data would be consistent with a model where tamoxifen-induced oxidative stress leads to activation of JNK and increased AP-1 activity (Schiff et al. 2000, Clarke et al. 2001). Such a chain of events could potentiate the agonistic effects of tamoxifen at AP-1 sites (Webb et al. 1995).

Activation of the p38 MAPK pathway has been reported to occur in response to a number of extracellular stimuli including growth factors, cytokines, physical and chemical stresses (New \& Han 1998). The downstream targets of p38 MAPK include further protein kinases and transcription factors. In cell lines expressing the ER, 4hydroxytamoxifen has been shown to activate the p38 MAPK pathway and to induce apoptosis (Zhang \& Shapiro 2000). Under these circumstances inhibition of the p38 signalling pathway greatly reduces the ability of 4hydroxytamoxifen to induce apoptosis. Moreover, in cell lines selected for resistance to 4-hydroxytamoxifen there is a correlation between ability to activate the p38 pathway and ability of this agent to induce apoptosis (Zhang \& Shapiro 2000). In a series previously mentioned, tissue microarrays were constructed from biopsy samples taken pre-treatment and at relapse from patients treated with adjuvant tamoxifen (Dowsett et al. 2003). In those patients who were ER-positive and HER2 positive at relapse there was uniformly high expression of p38 MAPK, suggesting that in this subset of patients, activation of ER may have occurred by this route.

\section{Summary and conclusions}

Over the last few years it has become apparent that ER transcriptional effects are not just determined by the ligand, but also by complex interactions between coregulatory molecules and multiple associated cell-signalling pathways. These interactions provide several plausible mechanisms by which breast cancer cells may circumvent a reliance on oestrogen-stimulated growth and become hormone-independent and tamoxifen-resistant. Altered levels of the expression of elements in these signalling pathways and co-regulatory molecules are common accompaniments in experimental models of endocrine resistance. Emerging clinical data suggests that such alterations may also play a part in resistance to tamoxifen in a clinical setting. A number of pharmacological agents targeting these pathways are available in the clinic or are in development. Further confirmation in clinical samples that the pathways described are determinants of tamoxifen resistance may allow the circumven- tion or prevention of tamoxifen resistance using rational therapeutic approaches. It will be important to consider that there may be multiple resistance pathways that are highly important in some patients but are irrelevant in others.

\section{References}

Anderson TI, Wooster R, Laake K, Collins N, Warren W, Skrede M, Elles R, Tveit KM, Johnston SR, Dowsett M, Olsen AO, Moller P, Stratton MR \& Borresen-Dale AL 1997 Screening for ESR mutations in breast and ovarian cancer patients. Human Mutation 9 531-536.

Angel P \& Karin M 1991 The role of Jun, Fos and the AP-1 complex in cell-proliferation and transformation. Biochimica et Biophysica Acta 1072 129-157 .

Anzick SL, Kononen J, Walker RL, Azorsa DO, Tanner MM, Guan XY, Sauter G, Kallioniemi OP, Trent JM \& Meltzer PS 1997 AIB1, a steroid receptor coactivator amplified in breast and ovarian cancer. Science 277 965-968.

Benz CC, Scott GK, Sarup JC, Johnson RM, Tripathy D, Coronado E, Shepard HM \& Osborne CK 1993 Estrogendependent, tamoxifen-resistant tumorigenic growth of MCF-7 cells transfected with HER2/neu. Breast Cancer Research and Treatment 24 85-95.

Berry DA, Muss HB, Thor AD, Dressler L, Liu ET, Broadwater G, Budman DR, Henderson IC, Barcos M, Hayes D \& Norton L 2000 HER-2/neu and p53 expression versus tamoxifen resistance in estrogen receptor-positive, nodepositive breast cancer. Journal of Clinical Oncology 18 3471-3479.

Bunone G, Briand PA, Miksicek RJ \& Picard D 1996 Activation of the unliganded estrogen receptor by EGF involves the MAP kinase pathway and direct phosphorylation. Embo J 15 2174-2183.

Campbell FC, Blamey RW, Elston CW, Morris AH, Nicholson RI, Griffiths K \& Haybittle JL 1981 Quantitative oestradiol receptor values in primary breast cancer and response of metastases to endocrine therapy. Lancet 2 1317-1319.

Campbell RA, Bhat-Nakshatri P, Patel NM, Constantinidou D, Ali S \& Nakshatri H 2001 Phosphatidylinositol 3-kinase/ AKT-mediated activation of estrogen receptor alpha: a new model for anti-estrogen resistance. Journal of Biological Chemistry 276 9817-9824.

Carlomagno C, Perrone F, Gallo C, De Laurentiis M, Lauria R, Morabito A, Pettinato G, Panico L, D'Antonio A, Bianco AR \& De Placido S 1996 c-erb B2 overexpression decreases the benefit of adjuvant tamoxifen in early-stage breast cancer without axillary lymph node metastases. Journal of Clinical Oncology 14 2702-2708.

Chan CM, Lykkesfeldt AE, Parker MG \& Dowsett M 1999 Expression of nuclear receptor interacting proteins TIF-1, SUG-1, receptor interacting protein 140, and corepressor SMRT in tamoxifen-resistant breast cancer. Clinical Cancer Research 5 3460-3467.

Chen H, Lin RJ, Schiltz RL, Chakravarti D, Nash A, Nagy L, Privalsky ML, Nakatani Y \& Evans RM 1997 Nuclear receptor coactivator ACTR is a novel histone 
acetyltransferase and forms a multimeric activation complex with $\mathrm{P} / \mathrm{CAF}$ and $\mathrm{CBP} / \mathrm{p} 300$. Cell 90 569-580.

Chen JD \& Evans RM 1995 A transcriptional co-repressor that interacts with nuclear hormone receptors. Nature 377 $454-457$.

Chung YL, Sheu ML, Yang SC, Lin CH \& Yen SH 2002 Resistance to tamoxifen-induced apoptosis is associated with direct interaction between Her2/neu and cell membrane estrogen receptor in breast cancer. International Journal of Cancer 97 306-312.

Clark AS, West K, Streicher S \& Dennis PA 2002 Constitutive and inducible Akt activity promotes resistance to chemotherapy, trastuzumab, or tamoxifen in breast cancer cells. Molecular Cancer Therapeutics 1 707-717.

Clarke R, Currier S, Kaplan O, Lovelace E, Boulay V, Gottesman MM \& Dickson RB 1992 Effect of P-glycoprotein expression on sensitivity to hormones in MCF-7 human breast cancer cells. Journal of the National Cancer Institute $\mathbf{8 4}$ 1506-1512.

Clarke R, Skaar TC, Bouker KB, Davis N, Lee YR, Welch JN \& Leonessa F 2001 Molecular and pharmacological aspects of antiestrogen resistance. Journal of Steroid Biochemistry and Molecular Biology 76 71-84.

Coutts AS \& Murphy LC 1998 Elevated mitogen-activated protein kinase activity in estrogen-nonresponsive human breast cancer cells. Cancer Research 58 4071-4074.

Cui X, Lazard Z, Zhang P, Hopp TA \& Lee AV 2003 Progesterone crosstalks with insulin-like growth factor signaling in breast cancer cells via induction of insulin receptor substrate-2. Oncogene 22 6937-6941.

Cui Y, Hopp T \& Fuqua SA 2002 A naturally occurring point mutation alters $\mathrm{ER} \alpha$ crosstalk with regulatory signaling pathways. San Antonio Breast Cancer Symposium 76 Abstract 168.

Cuzick J, Powles T, Veronesi U, Forbes J, Edwards R, Ashley S \& Boyle P 2003 Overview of the main outcomes in breastcancer prevention trials. Lancet 361 296-300.

Datta SR, Brunet A \& Greenberg ME 1999 Cellular survival: a play in three Akts. Genes and Development 13 2905-2927.

De Nardo D, Kim H, Thorn C, Wu K, Lee AV \& Brown PH 2003 Estrogen's ability to stimulate breast cancer growth does not require ER DNA binding. San Antonio Breast Cancer Symposium 82 Abstract 1002.

De Placido S, De Laurentiis M, Carlomagno C, Gallo C, Perrone F, Pepe S, Ruggiero A, Marinelli A, Pagliarulo C, Panico L, Pettinato G, Petrella G \& Bianco AR 2003 Twenty-year results of the Naples GUN Randomized Trial: Predictive factors of adjavant tamoxifen efficacy in early breast cancer. Clinical Cancer Research 9 1039-1046.

Dotzlaw H, Leygue E, Watson PH \& Murphy LC 1999 Estrogen receptor-beta messenger RNA expression in human breast tumor biopsies: relationship to steroid receptor status and regulation by progestins. Cancer Research 59 529-532.

Dowsett M, Houghton J, Baum M, Salter J, A'Hern R, Iden C \& Farndon J 1999 ER, PgR, c-ERBB2 and EGFR in patients randomised to adjuvant tamoxifen: combinations of biomarkers as discriminants of treatment benefit. San Antonio Breast Cancer Symposium 57 Abstract 222.
Dowsett M, Harper-Wynne C, Boeddinghaus I, Salter J, Hills M, Dixon M, Ebbs S, Gui G, Sacks N \& Smith I 2001 HER-2 amplification impedes the antiproliferative effects of hormone therapy in estrogen receptor-positive primary breast cancer. Cancer Research 61 8452-8458.

Dowsett M \& Haynes BP 2003 Hormonal effects of aromatase inhibitors: focus on premenopausal effects and interaction with tamoxifen. Journal of Steroid Biochemistry and Molecular Biology 86 255-263.

Dowsett M, Gutierrez C, Moshin S, Schiff R, Detre S, Johnston SR \& Osborne CK 2003 Molecular changes in tamoxifenrelapsed breast cancer: Realtionship between ER, HER2 and P38-MAP-kinase, Proceedings of the American Society of Clinical Oncology, 39th Annual Meeting, Chicago, IL, USA. 22 Abstract 7.

Dumont JA, Bitonti AJ, Wallace CD, Baumann RJ, Cashman EA \& Cross-Doersen DE 1996 Progression of MCF-7 breast cancer cells to antiestrogen-resistant phenotype is accompanied by elevated levels of AP-1 DNA-binding activity. Cell Growth and Differentiation 7 351-359.

Early Breast Cancer Trialists' Collaborative Group 1998 Tamoxifen for early breast cancer an overview of the randomised trials. Lancet 351 1451-1467.

Ellis MJ, Coop A, Singh B, Mauriac L, Llombert-Cussac A, Janicke F, Miller WR, Evans DB, Dugan M, Brady C, Quebe-Fehling E \& Borgs M 2001 Letrozole is more effective neoadjuvant endocrine therapy than tamoxifen for ErbB-1- and/or ErbB-2-positive, estrogen receptor- positive primary breast cancer: evidence from a phase III randomized trial. Journal of Clinical Oncology 19 3808-3816.

Fahey SM, Tormey DC \& Jordan VC 1989 Long-term adjuvant tamoxifen in node-positive breast cancer: A metabolic and pilot clinical study. Breast Cancer Research and Treatment 14154.

Font de Mora J \& Brown M 2000 AIB1 is a conduit for kinasemediated growth factor signaling to the estrogen receptor. Molecular and Cellular Biology 20 5041-5047.

Frasor J, Danes JM, Komm B, Chang KCN, Lyttle R \& Katzenellenbogen BS 2003 Profiling of estrogen up- and down-regulated gene expression in human breast cancers cells: insights into gene networks and pathways underlying estrogenic control of proliferation and cell phenotype. Endocrinology 144 4562-4574.

Fuqua SA, Schiff R, Parra I, Friedrichs WE, Su JL, McKee DD, Slentz-Kesler K, Moore LB, Willson TM \& Moore JT 1999 Expression of wild-type estrogen receptor beta and variant isoforms in human breast cancer. Cancer Research 59 5425-5428.

Fuqua SA, Schiff R, Parra I, Moore JT, Mohsin SK, Osborne CK, Clark GM \& Allred DC 2003 Estrogen receptor beta protein in human breast cancer: correlation with clinical tumor parameters. Cancer Research 63 2434-2439.

Fuqua SA, Wiltschke C, Zhang QX, Borg A, Castles CG, Friedrichs WE, Hopp T, Hilsenbeck S, Mohsin S, O’Connell P \& Allred DC 2000 A hypersensitive estrogen receptor-alpha mutation in premalignant breast lesions. Cancer Research $\mathbf{6 0}$ 4026-4029.

Gee JM, Robertson JF, Ellis IO \& Nicholson RI 2001 Phosphorylation of ERK1/2 mitogen-activated protein kinase 
is associated with poor response to anti-hormonal therapy and decreased patient survival in clinical breast cancer. International Journal of Cancer 95 247-254.

Gronemeyer H 1991 Transcription activation by estrogen and progesterone receptors. Annual Review of Genetics 25 89-123.

Heinzel T, Lavinsky RM, Mullen TM, Soderstrom M, Laherty CD, Torchia J, Yang WM, Brard G, Ngo SD, Davie JR, Seto E, Eisenman RN, Rose DW, Glass CK \& Rosenfeld MG 1997 A complex containing N-CoR, mSin 3 and histone deacetylase mediates transcriptional repression. Nature $38743-48$.

Hong SH \& Privalsky ML 2000 The SMRT corepressor is regulated by a MEK-1 kinase pathway: inhibition of corepressor function is associated with SMRT phosphorylation and nuclear export. Molecular and Cellular Biology 20 6612-6625.

Horlein AJ, Naar AM, Heinzel T, Torchia J, Gloss B, Kurokawa R, Ryan A, Kamei Y, Soderstrom M, Glass CK et al. 1995 Ligand-independent repression by the thyroid hormone receptor mediated by a nuclear receptor co-repressor. Nature 377 397-404.

Howell A, Robertson JF, Quaresma Albano J, Aschermannova A, Mauriac L, Kleeberg UR, Vergote I, Erikstein B, Webster A \& Morris C 2002 Fulvestrant, formerly ICI 182,780 , is as effective as anastrozole in postmenopausal women with advanced breast cancer progressing after prior endocrine treatment. Journal of Clinical Oncology 20 3396-3403.

Ingle JN, Mailliard JA, Schaid DJ, Krook JE, Gesme DH Jr, Windschitl HE, Pfeifle DM, Etzell PS, Gerstner JG, Long HJ et al. 1991 A double-blind trial of tamoxifen plus prednisolone versus tamoxifen plus placebo in postmenopausal women with metastatic breast cancer. A collaborative trial of the North Central Cancer Treatment Group and Mayo Clinic. Cancer 68 34-39.

Ito M \& Roeder RG The TRAP/SMCC/2001 Mediator complex and thyroid hormone receptor function. Trends in Endocrinology and Metabolism 12 127-134.

Iwase H, Zhang Z, Omoto Y, Sugiura H, Yamashita H, Toyama T, Iwata H \& Kobayashi S 2003 Clinical significance of the expression of estrogen receptors alpha and beta for endocrine therapy of breast cancer. Cancer, Chemotherapy and Pharmacology 52 (Suppl 1) S34-S38 .

Jaiyesimi IA, Buzdar AU, Decker DA \& Hortobagyi GN 1995 Use of tamoxifen for breast cancer: twenty-eight years later. Journal of Clinical Oncology 13 513-529.

Jarvinen TA, Pelto-Huikko M, Holli K \& Isola J 2000 Estrogen receptor beta is coexpressed with ERalpha and PR and associated with nodal status, grade, and proliferation rate in breast cancer. American Journal of Pathology 156 29-35.

Joel PB, Smith J, Sturgill TW, Fisher TL, Blenis J \& Lannigan DA 1998 pp90rsk1 regulates estrogen receptor-mediated transcription through phosphorylation of Ser-167. Molecular and Cellular Biology 18 1978-1984.

Johnston SR, Haynes BP, Smith IE, Jarman M, Sacks NP, Ebbs SR \& Dowsett M 1993 Acquired tamoxifen resistance in human breast cancer and reduced intra-tumoral drug concentration. Lancet 342 1521-1522.
Johnston SR, Lu B, Scott GK, Kushner PJ, Smith IE, Dowsett M \& Benz CC 1999 Increased activator protein-1 DNA binding and c-Jun NH2-terminal kinase activity in human breast tumors with acquired tamoxifen resistance. Clinical Cancer Research 5 251-256.

Johnston SR, Saccani-Jotti G, Smith IE, Salter J, Newby J, Coppen M, Ebbs SR \& Dowsett M 1995 Changes in estrogen receptor, progesterone receptor, and $\mathrm{pS} 2$ expression in tamoxifen-resistant human breast cancer. Cancer Research $\mathbf{5 5}$ 3331-3338.

Kahlert S, Nuedling S, van Eickels M, Vetter H, Meyer R \& Grohe C 2000 Estrogen receptor alpha rapidly activates the IGF-1 receptor pathway. Journal of Biological Chemistry 275 18447-18453.

Karnik PS, Kulkarni S, Liu XP, Budd GT \& Bukowski RM 1994 Estrogen receptor mutations in tamoxifen-resistant breast cancer. Cancer Research 54 349-353.

Kato S, Endoh H, Masuhiro Y, Kitamoto T, Uchiyama S, Sasaki $\mathrm{H}$, Masushige S, Gotoh Y, Nishida E, Kawashima $\mathrm{H}$ et al. 1995 Activation of the estrogen receptor through phosphorylation by mitogen-activated protein kinase. Science 270 1491-1494.

Kelly MJ \& Levin ER 2001 Rapid actions of plasma membrane estrogen receptors. Trends in Endocrinology and Metabolism $12152-156$.

Kim HP, Lee JY, Jeong JK, Bae SW, Lee HK \& Jo I 1999 Nongenomic stimulation of nitric oxide release by estrogen is mediated by estrogen receptor alpha localized in caveolae. Biochemical and Biophysical Research Communications 263 257-262.

Knoop AS, Bentzen SM, Nielsen MM, Rasmussen BB \& Rose C 2001 Value of epidermal growth factor receptor, HER2, p53, and steroid receptors in predicting the efficacy of tamoxifen in high-risk postmenopausal breast cancer patients. Journal of Clinical Oncology 19 3376-3384.

Knowlden JM, Hutcheson IR, Jones HE, Madden T, Gee JMW, Harper ME, Barrow D, Wakeling AE \& Nicholson RI 2003 Elevated levels of epidermal growth factor receptor/c-erbB2 heterodimers mediate an autocrine Growth Regulationatory pathway in tamoxifen-resistant MCF-7 cells. Endocrinology 144 1032-1044.

Kuiper GG, Enmark E, Pelto-Huikko M, Nilsson S \& Gustafsson JA 1996 Cloning of a novel receptor expressed in rat prostate and ovary. PNAS 93 5925-5930.

Kurokawa H \& Arteaga CL 2001 Inhibition of erbB receptor (HER) tyrosine kinases as a strategy to abrogate antiestrogen resistance in human breast cancer. Clinical Cancer Research 7 4411s-4442s.

Kushner PJ, Agard DA, Greene GL, Scanlan TS, Shiau AK, Uht RM \& Webb P 2000 Estrogen receptor pathways to AP-1. Journal of Steroid Biochemistry and Molecular Biology $\mathbf{7 4}$ 311-317.

Kyriakis JM, Banerjee P, Nikolakaki E, Dai T, Rubie EA, Ahmad MF, Avruch J \& Woodgett JR 1994 The stressactivated protein kinase subfamily of c-Jun kinases. Nature 369 156-160.

Lavinsky RM, Jepsen K, Heinzel T, Torchia J, Mullen TM, Schiff R, Del-Rio AL, Ricote M, Ngo S, Gemsch J, Hilsenbeck SG, Osborne CK, Glass CK, Rosenfeld MG \& 
Rose DW 1998 Diverse signaling pathways modulate nuclear receptor recruitment of N-CoR and SMRT complexes. PNAS 95 2920-2925.

Leo C \& Chen JD 2000 The SRC family of nuclear receptor coactivators. Gene $2451-11$.

Leygue E, Dotzlaw H, Watson PH \& Murphy LC 1999 Expression of estrogen receptor beta1, beta2, and beta5 messenger RNAs in human breast tissue. Cancer Research 59 1175-1179.

Li L, Haynes MP \& Bender JR 2003 Plasma membrane localization and function of the estrogen receptor alpha variant (ER46) in human endothelial cells. PNAS 100 $4807-4812$.

Lippman ME \& Allegra JC 1980 Quantitative estrogen receptor analyses: the response to endocrine and cytotoxic chemotherapy in human breast cancer and the disease-free interval. Cancer 46 2829-2834.

List HJ, Lauritsen KJ, Reiter R, Powers C, Wellstein A \& Riegel AT 2001 Ribozyme targeting demonstrates that the nuclear receptor coactivator AIB1 is a rate-limiting factor for estrogen-dependent growth of human MCF-7 breast cancer cells. Journal of Biological Chemistry 276 23763-23768.

MacGregor Schafer J, Liu H, Bentrem DJ, Zapf JW \& Jordan VC 2000 Allosteric silencing of activating function 1 in the 4 hydroxytamoxifen estrogen receptor complex is induced by substituting glycine for aspartate at amino acid 351. Cancer Research 60 5097-5105.

Mahfoudi A, Roulet E, Dauvois S, Parker MG \& Wahli W 1995 Specific mutations in the estrogen receptor change the properties of antiestrogens to full agonists. PNAS 92 4206-4210.

Mann S, Laucirica R, Carlson N, Younes PS, Ali N, Younes A, Li Y \& Younes M 2001 Estrogen receptor beta expression in invasive breast cancer. Human Pathology 32 113-118.

Martens J, Nimmrich I, Koenig T, Look M, Harbeck N \& Model F 2003 Epigenetic signature predicts failure of endocrine therapy in patients with recurrent breast cancer. San Antonio Breast Cancer Symposium Abstract 313.

McClelland RA, Barrow D, Madden TA, Dutkowski CM, Pamment J, Knowlden JM, Gee JM \& Nicholson RI 2001 Enhanced epidermal growth factor receptor signaling in MCF7 breast cancer cells after long-term culture in the presence of the pure antiestrogen ICI 182,780 (Faslodex). Endocrinology 142 2776-2788.

McDonnell DP, Clemm DL, Hermann T, Goldman ME \& Pike JW 1995 Analysis of estrogen receptor function in vitro reveals three distinct classes of antiestrogens. Molecular Endocrinology 9 659-669.

McKenna NJ, Lanz RB \& O'Malley BW 1999 Nuclear receptor coregulators: cellular and molecular biology. Endocrine Reviews 20 321-344.

Migliaccio A, Castoria G, Di Domenico M, de Falco A, Bilancio A, Lombardi M, Bottero D, Varricchio L, Nanayakkara M, Rotondi A \& Auricchio F 2002 Sex steroid hormones act as growth factors. Journal of Steroid Biochemistry and Molecular Biology 83 31-35.
Mosselman S, Polman J \& Dijkema R 1996 ER $\beta$ : identification and characterization of a novel human estrogen receptor. FEBS Letters 392 49-53.

Nagy L, Kao HY, Chakravarti D, Lin RJ, Hassig CA, Ayer DE, Schreiber SL \& Evans RM 1997 Nuclear receptor repression mediated by a complex containing SMRT, mSin3A, and histone deacetylase. Cell 89 373-380 .

New L \& Han J 1998 The p38 MAP kinase pathway and its biological function. Trends in Cardiovascular Medicine $\mathbf{8}$ 220-229.

Newby JC, Johnston SR, Smith IE \& Dowsett M 1997 Expression of epidermal growth factor receptor and c-erbB2 during the development of tamoxifen resistance in human breast cancer. Clinical Cancer Research 3 1643-1651.

Nicholson RI, Hutcheson IR, Harper ME, Knowlden JM, Barrow D, McClelland RA, Jones HE, Wakeling AE \& Gee JM 2001 Modulation of epidermal growth factor receptor in endocrine-resistant, oestrogen receptor-positive breast cancer. Endocrine-Related Cancer 8 175-182.

Omoto Y, Inoue S, Ogawa S, Toyama T, Yamashita H, Muramatsu M, Kobayashi S \& Iwase H 2001 Clinical value of the wild-type estrogen receptor beta expression in breast cancer. Cancer Letters 163 207-212.

Osborne CK, Coronado E, Allred DC, Wiebe V \& DeGregorio M 1991 Acquired tamoxifen resistance: correlation with reduced breast tumor levels of tamoxifen and isomerization of trans-4-hydroxytamoxifen. Journal of the National Cancer Institute 83 1477-1482.

Osborne CK, Schiff R, Fuqua SA \& Shou J 2001 Estrogen receptor: current understanding of its activation and modulation. Clinical Cancer Research 7 4338s-4342s; discussion 4411 s- $4412 \mathrm{~s}$.

Osborne CK, Pippen J, Jones SE, Parker LM, Ellis M, Come S, Gertler SZ, May JT, Burton G, Dimery I, Webster A, Morris C, Elledge R \& Buzdar A 2002 Double-blind, randomized trial comparing the efficacy and tolerability of fulvestrant versus anastrozole in postmenopausal women with advanced breast cancer progressing on prior endocrine therapy: results of a North American trial. Journal of Clinical Oncology 20 3386-3395.

Osborne CK, Bardou V, Hopp TA, Chamness GC, Hilsenbeck SG, Fuqua SA, Wong J, Allred DC, Clark GM \& Schiff R 2003 Role of the estrogen receptor coactivator AIB1 (SRC-3) and HER-2/neu in tamoxifen resistance in breast cancer. Journal of the National Cancer Institute 95 353-361.

Ottaviano YL, Issa JP, Parl FF, Smith HS, Baylin SB \& Davidson NE 1994 Methylation of the estrogen receptor gene $\mathrm{CpG}$ island marks loss of estrogen receptor expression in human breast cancer cells. Cancer Research 54 2552-2555.

Paech K, Webb P, Kuiper GG, Nilsson S, Gustafsson J, Kushner PJ \& Scanlan TS 1997 Differential ligand activation of estrogen receptors ERalpha and ERbeta at AP-1 sites. Science 277 1508-1510.

Palmieri C, Cheng GJ, Saji S, Zelada-Hedman M, Warri A, Weihua Z, Van Noorden S, Wahlstrom T, Coombes RC, Warner M \& Gustafsson JA 2002 Estrogen receptor beta in breast cancer. Endocrine-Related Cancer 9 1-13. 
Paridaens R, Sylvester RJ, Ferrazzi E, Legros N, Leclercq G \& Heuson JC 1980 Clinical significance of the quantitative assessment of estrogen receptors in advanced breast cancer. Cancer 46 2889-2895.

Pavlik EJ, Nelson K, Srinivasan S, Powell DE, Kenady DE, DePriest PD, Gallion HH \& van Nagell JR Jr 1992 Resistance to tamoxifen with persisting sensitivity to estrogen: possible mediation by excessive antiestrogen binding site activity. Cancer Research 52 4106-4112.

Peto R, Boreham J, Clarke M, Davies C \& Beral V 2000 UK and USA breast cancer deaths down $25 \%$ in year 2000 at ages 20-69 years. Lancet 3551822.

Pietras RJ, Arboleda J, Reese DM, Wongvipat N, Pegram MD, Ramos L, Gorman CM, Parker MG, Sliwkowski MX \& Slamon DJ 1995 HER-2 tyrosine kinase pathway targets estrogen receptor and promotes hormone-independent growth in human breast cancer cells. Oncogene $\mathbf{1 0}$ 2435-2446.

Ravdin PM, Fritz NF, Tormey DC \& Jordan VC 1988 Endocrine status of premenopausal node-positive breast cancer patients following adjuvant chemotherapy and long-term tamoxifen. Cancer Research 48 1026-1029.

Razandi M, Pedram A, Park ST \& Levin ER 2003 Proximal events in signaling by plasma membrane estrogen receptors. Journal of Biological Chemistry 278 2701-2712.

Ring A \& Dowsett M 2003 Human epidermal growth factor receptor-2 and hormonal therapies: clinical implications. Clinical Breast Cancer 4 (Suppl 1) S34-S41.

Roodi N, Bailey LR, Kao WY, Verrier CS, Yee CJ, Dupont WD \& Parl FF 1995 Estrogen receptor gene analysis in estrogen receptor-positive and receptor-negative primary breast cancer. Journal of the National Cancer Institute 87 446-451.

Roger P, Sahla ME, Makela S, Gustaffson JA, Baldet P, Rochefort H 2001 Decreased expression of estrogen receptor beta protein in proliferative preinvasive mammary tumours. Cancer Research 61 2537-2541.

Schiff R, Reddy P, Ahotupa M, Coronado-Heinsohn E, Grim M \& Hilsenbeck SG 2000 Oxidative stress and AP-1 activity in tamoxifen-resistant breast tumour in vivo. Journal of National Cancer Institute 29 1926-1934.

Schiff R, Massarweh S, Shou J \& Osborne CK 2003 Breast cancer endocrine resistance: how growth factor signaling and estrogen receptor coregulators modulate response. Clinical Cancer Research 9 447S-454S.

Shiau AK, Barstad D, Loria PM, Cheng L, Kushner PJ, Agard DA \& Greene GL 1998 The structural basis of estrogen receptor/coactivator recognition and the antagonism of this interaction by tamoxifen. Cell 95 927-937.

Shim WS, Conaway M, Masamura S, Yue W, Wang JP, Kmar R \& Santen RJ 2000 Estradiol hypersensitivity and mitogenactivated protein kinase expression in long-term estrogen deprived human breast cancer cells in vivo. Endocrinology 141 396-405.

Simoncini T, Hafezi-Moghadam A, Brazil DP, Ley K, Chin WW \& Liao JK 2000 Interaction of oestrogen receptor with the regulatory subunit of phosphatidylinositol-3-OH kinase. Nature 407 538-541.

Smith CL, Nawaz Z \& O'Malley BW 1997 Coactivator and corepressor regulation of the agonist/antagonist activity of the mixed antiestrogen, 4-hydroxytamoxifen. Molecular Endocrinology 11 657-666.

Smith IE, Dowsett M, Ebbs SR, Dixon JM, Skene A, Blohmer J-U, Ashley SE, Francis S, Boeddinghams I \& Walsh G 2004 Neoadjuvant treatment of postmenopausal breast cancer with anastrozole, tamoxifen or both in combination: the IMPACT multicentre double-blind randomised trial. Journal of Clinical Oncology (In Press).

Speirs V, Malone C, Walton DS, Kerin MJ \& Atkin SL 1999 Increased expression of estrogen receptor beta mRNA in tamoxifen-resistant breast cancer patients. Cancer Research $595421-5424$.

Stal O, Borg A, Ferno M, Kallstrom AC, Malmstrom P \& Nordenskjold B 2000 ErbB2 status and the benefit from two or five years of adjuvant tamoxifen in postmenopausal early stage breast cancer. Annals of Oncology 11 1545-1550.

Stearns V, Johnson MD, Rae JM, Morocho A, Novielli A, Bhargava P, Hayes DF, Desta Z \& Flockhart DA 2003 Active tamoxifen metabolite plasma concentrations after coadministration of tamoxifen and the selective serotonin reuptake inhibitor paroxetine. Journal of the National Cancer Institute 95 1758-1764.

Stewart J, King R, Hayward J \& Rubens R 1982 Estrogen and progesterone receptors: correlation of response rates, site and timing of receptor analysis. Breast Cancer Research Treatment 2 243-250.

Sudarsanam P \& Winston F 2000 The Swi/Snf family nucleosome-remodeling complexes and transcriptional control. Trends in Genetics 16 345-351.

Sun M, Paciga JE, Feldman RI, Yuan Z, Coppola D, Lu YY, Shelley SA, Nicosia SV \& Cheng JQ 2001

Phosphatidylinositol-3-OH kinase (PI3K) /AKT2, activated in breast cancer, regulates and is induced by estrogen receptor alpha (ERalpha) via interaction between ERalpha and PI3K. Cancer Research 61 5985-5991.

Tzukerman MT, Esty A, Santiso-Mere D, Danielian P, Parker MG, Stein RB, Pike JW \& McDonnell DP 1994 Human estrogen receptor transactivational capacity is determined by both cellular and promoter context and mediated by two functionally distinct intramolecular regions. Molecular Endocrinology 8 21-30.

Vo N \& Goodman RH 2001 CREB-binding protein and p300 in transcriptional regulation. Journal of Biological Chemistry 276 13505-13508.

Webb P, Lopez GN, Uht RM \& Kushner PJ 1995 Tamoxifen activation of the estrogen receptor/AP-1 pathway: potential origin for the cell-specific estrogen-like effects of antiestrogens. Molecular Endocrinology 9 443-456.

Webb P, Nguyen P, Shinsako J, Anderson C, Feng W, Nguyen MP, Chen D, Huang SM, Subramanian S, McKinerney E, Katzenellenbogen BS, Stallcup MR \& Kushner PJ 1998 Estrogen receptor activation function 1 works by binding p160 coactivator proteins. Molecular Endocrinology 12 $1605-1618$

Wolf DM \& Jordan VC 1994 The estrogen receptor from a tamoxifen stimulated MCF-7 tumor variant contains a point mutation in the ligand-binding domain. Breast Cancer Research Treatment 31 129-138. 
Wong CW, McNally C, Nickbarg E, Komm BS \& Cheskis BJ 2002 Estrogen receptor-interacting protein that modulates its nongenomic activity-crosstalk with Src/Erk phosphorylation cascade. PNAS 99 14783-14788.

Wu RC, Qin J, Hashimoto Y, Wong J, Xu J, Tsai SY, Tsai MJ \& O'Malley BW 2002 Regulation of SRC-3 (pCIP/ACTR/AIB1/RAC-3/TRAM-1) Coactivator activity by I kappa B kinase. Molecular and Cellular Biology 22 3549-3561.
Zhang CC \& Shapiro DJ 2000 Activation of the p38 mitogenactivated protein kinase pathway by estrogen or by 4hydroxytamoxifen is coupled to estrogen receptor-induced apoptosis. Journal of Biological Chemistry 75 479-486.

Zhang QX, Borg A, Wolf DM, Oesterreich S \& Fuqua SA 1997 An estrogen receptor mutant with strong hormoneindependent activity from a metastatic breast cancer. Cancer Research 57 1244-1249. 